$\xi=-1$

\title{
The Influence of Interest Rates on Rental Rate in the United States Islamic Home Financing
}

\author{
Jamilu A Salihu ${ }^{1 *}$ \\ ${ }^{1}$ Kano State Polytechnic \\ * Corresponding author E-mail: jameelsalihu@yahoo.com
}

\begin{abstract}
The purpose of this paper is to investigate, whether the rental rate is free from the influence of interest rates on Islamic home financing. The study considers some selected macroeconomic variables to analyze the influence of interest rates on the rental rate. The study focuses on the United States data covering from the first quarter of 1990 to the last quarter of 2016. The study adopts Autoregressive distributed lags (ARDL) model to analyze the long-run and short-run relationships between the rental rate and the macroeconomic variables. The study finds consistent evidence that rental rate is free from the influence of short term and long term interest rates in both long-run equilibrium and short-run dynamic results in the United States Islamic home financing. Hence, the rental rate could be accepted as an alternative to interest rates in Islamic home financing. The result contributes towards finding that the rental rate is free from the influence of interest rate in Islamic home financing. To the best of the author's knowledge, the present study is the first of its kind which empirically investigates the influence of interest rates on the rental rate in Islamic home financing.
\end{abstract}

Keywords: ARDL; Rental rate; Islam home finance.

\section{Introduction}

The purpose of establishing Islamic finance is to avoid interest rate in the economy due to its injustice and uncertainty. The interest rate destabilized the economy and it is the main cause of the recent (2007) global economic crisis. Hence, the issue of interest rate reflects the need for sharia-compliant financing products in the existing economy. The most common Islamic financing products in Islamic home financing system are Bay Bithaman Ajil (BBA) and Musharakah Mutanaqisah (MM) contracts. BBA is referred to as sales in a deferred payment. It provides the buyer with the benefit of installment and deferred payments, and the same time provides the seller with additional profit. The concept of BBA is on the debt financing where the financial institutions purchase a property and sell it to the customer with an increase of profit margin. The previous studies (Meera \& Abdul Razak, 2009; Rama, 2010; Yusof, Kassim, Majid, \& Hamid, 2011) proved that the profit margin is determined by the interest rate. Hence, the issue of the interest rate on BBA gave the birth to the introduction of Musharakah Mutanaqisah to tackle the issue of relying on the interest rate.

Musharakah Mutanaqisah (MM) was first established by Islamic Cooperative Housing Corporation (ICHC) in 1981 in Toronto Canada (Abd Karim \& Gee, 2008; Fauziah, Taib, Ramayah, \& Abdul Razak, 2008; Meera \& Abdul Razak, 2009). MM is based on the equity financing between the bank and the customer. The Islamic mode of home financing is commonly used in the United States (Yusof et al., 2011). Musharakah Mustanaqisah is a combination of two Arabic words that mean diminishing partnership. MM contract is an Islamic home financing contract that revolves around three separate but related concepts of partnership (Musharaka), lease (Ijarah), and sales (al-Bay) (Abd Karim \&
Gee, 2008; Muhamad \& Rahman, 2013; Osmani \& Abdullah, 2010; Smolo \& Kabir Hassan, 2011). For the first concept partnership, the customer and the bank jointly co-own a property. For the second concept lease, the financier partner leases the share to the client partner based on the agreed rental price. The third concept sales, the customer buys the share of the financier gradually until the customer possessed the whole share of the property. Therefore, $\mathrm{MM}$ is diminishing partnership concept that is based on rental rate The issue is that the interest rate is used as a benchmark to determine the rental rate (Muhamad \& Rahman, 2013) and, thus, involved uncertainty in the rental rate. Hence, for the transaction to be interest-free, the rental rate should be free from the impact of interest rate.

Therefore, the present study tries to investigate the macroeconomic determinants of rental rate to ensure that the rental rate is free from any influence of interest rate, for it to serve as an alternative to the interest rate in Islamic home financing. The study employed Autoregressive Distributed Lags (ARDL) using the United States data from the first quarter of 1990 to the fourth quarter of 2016. The macroeconomic variables such as Gross Domestic Product (GDP), inflation rate, employment rate, share price, exchange rate and interest rate are the macroeconomic factors that determine the rental rate (Simon, Achsani, Manurung, \& Sembel, 2015). The variables are considered as the demand factors and they will eventually have an impact on the rental rate in the housing market. Hence, the study considers the variables to investigate their influence on the rental rate.

Previous studies (Meera \& Abdul Razak, 2009; Rama, 2010; Yusof et al., 2011) recommended rental rate as an alternative to the interest rate in Islamic home financing. The interest rate is haram in Islamic financing. Therefore, the recommended variable as an alternative to interest rate should be free from the influence of interest rate. The present study has not come across any study that is conducted for the purpose of testing the influence of inter- 
est rate on the rental rate. There are a lot of studies that focused on the determinants of house price and the rental rate (Latif, 2015; Marco, 2008; Salihu \& Yusof, 2017). However, little attention has been given to the determinants of the rental rate for Islamic home financing. The study focuses more on the interest rate for the purpose of coming up with the rental rate that is free from the influence of interest rate in the Islamic home financing.

The present study expects to make significant contributions. To the best knowledge of the writer, this is the first study focusing on the influence of interest rate to find out whether the rental rate is free from the impact of interest in the United States Islamic Home home financing. Meanwhile, the study is the first of its kind to focus on the influence of two major categories of interest rates that constitute all type of interest that either fall under long-term or short-term interest rates.

The remainder of the paper is organized as follows: Section two reviews the relevant previous studies; Section three discusses the empirical methodology; section four presents the results and discussion of the findings, and lastly, section four contains the general conclusions of the study.

\section{Literature Review}

In efforts to understand the Islamic home financing and the determinants of rental rate, this section highlights the Islamic home financing in the housing market. Subsequently, it reviews the major determinants of rental rate in the existing literature.

\subsection{Overview of Islamic Home Financing in the United States}

The overview of Islamic finance in the United States is per back to the mid of the 1980s, a small number of Muslims living in the United States dreamt of owning a property based on Islamic financing that is interest-free. This is in compelled to violate dealing with interest for the basic requirement of faith among the Muslim community. This serves as an initial idea for shariacompliant real investment product in the United States. The achievement of the implementation of Islamic financing is through the founding of Amana funds in Washington and American Finance House in Califonia in the 1980s. The American Finance House provides Islamic home financing called Lariba. The word Lariba is an Arabic word which means no interest and the word Amana means trust.

In the middle of 1990s, Islamic financing system has traditionally been recognized in financing transactions at the consumer level by the Office of the Comptroller of the Currency (OCC). The recognition of Ijarah and Murabahah Islamic financing models by the OCC have contributed to validating the transactions of residential property. The sharia-compliant products were introduced to the United States national market. In the year 1998, the United Bank of Kuwait (UKB) offered Ijarah Wa Iqtina (leasing and acquisition) Islamic financing product in the United States. The product involves a net residential lease to own a house (Alharbi, 2015). Apart from the foreign bank that operates Islamic home finance in the United States, the American based Devan Bank is the dominant player in Islamic home financing (Ranzini, 2007). The bank offered Ijarah Muntahiyya Bi Tamleek (IMBT) and Murabahah. The IMBT is translated as leasing ending in ownership. Murabahah means cost plus arrangement (Yusof et al., 2011). Murabahah is sometimes called Bay' Bithaman Ajil (BBA) BBA is translated as sales in a deferred payment (Meera \& Abdul Razak, 2005). Similarly, the Hong Kong and Shanghai Banking Corporation, popularly known as HSBC is another major player in the Islamic financial market in the United States.

The issue is that the interest rate determines the mode of Islamic financing popular practices by the banks in the United States. The previous studies have recommended that the Islamic home finance should be determined by the rental rates rather than interest rates.
Hence, the present study empirically investigates the rental rate, to ensure that that the recommended alternative to the interest rate in the United States Islamic home financing can be free from the influence of interest rate.

\subsection{Determinants of Rental Rate}

This subsection of the literature review focuses on the relevant studies on the determinants of house price and rental price. The study of Marco (2007), is among the earlier studies that were conducted in the United States. The study focused on the location of the property and demographic attributes to determine the rental rate in the New York City neighborhoods. The study generated the median monthly rent data from five community districts in the city. The result of the study showed that the demographic attributes are the significant determinants of the rental rate. The present study focuses on the macroeconomic factors that are more volatile similar to monthly rent compared to demographic attributes.

Yusof et al. (2011) identified the macroeconomic determinants of rental price and lending rate in Malaysian housing market from 1990 until 2006 using quarterly data. The independent variables are gross domestic product (GDP), inflation rate, exchange rate and interest rate. The study considered Treasury bills as a proxy of interest rate, which focused only on the short-term interest rate. The study employed Autoregressive distributed lags (ARDL), Granger causality and multivariate causality. The purpose of the study is to investigate whether the rental price would serve as a benchmark for Islamic home financing compared to lending rate. The result of the findings pointed out that rental price is significantly affected by the GDP and Treasury Bills. Therefore, the result showed that the rental price relied on the short-term interest rate in the Malaysian housing market for the period of the study. Another issue of the study is that lending rate is based on the interest rate financing that is against sharia. Whereas rental rate is sharia-compliant provided it is practiced based on sharia. Therefore, the variables are incomparable in the Islamic financing.

Latif (2015) examined the influence of immigration flow on property rent in Canada for the period from 1983 to 2010 annual data. The independent variables are GDP, immigration flow, and unemployment rate. The study considered both Fully Modified Ordinary Least Square (FMOLS) and Dynamic Ordinary Least Square (DOLS). The findings suggested that immigration flow has a significant influence on property rent. This is as a result of employment opportunity for the new immigrants and employment rate positively influences the housing rent and, thus, robust the result of the study that found a negative relationship between unemployment rate and the housing rent. The result also indicates that the middle-class housing rent is tied to their employment. The study suggested for further investigation on the relationship between macroeconomic variables and house rent.

Simon et al. (2015) examined the macroeconomic factors that affect the office rental rates and selling prices office space. The study used Indonesian quarterly data from the first quarter of 1996 to the last quarter of 2012. The result of the Vector Error Correction Model (VECM) shows the presence of a long-run relationship between the macroeconomic variables and office rental rate. The long-run results of the VECM further indicated that interest rate, inflation rate, exchange rate and employment service positively influenced the office rental rate. The result of Impulse Response Function (IRF) showed that office rental rate positively responded to independent variables of interest rates, inflation, exchange rate and employment rate. At variance decomposition, the result illustrated that the office rental rate is predominantly influenced by employment services sector, exchange rate, inflation, interest rates and GDP respectively.

Salihu and Yusof (2017) empirically examined the determinants of house prices in the South African housing market. The study employed ARDL technique to determine the influence of the selected macroeconomic variables on South African house prices. The study considered the quarterly data from the first quarter of 2006 
to the last quarter of 2015. The ARDL bound test result indicates the long-run cointegration of the model. The inflation rate, longterm and short-term interest rate significantly influence house prices. Inflation rate and long-term interest rate negatively affect house price, while short-term interest rate positively affects housing prices. The result further shows GDP and exchange rate variables are insignificant for determining the house price in this context.

\section{Methodology/Materials}

The present study adopts the Autoregressive distributed lags (ARDL) that was introduced by Pesaran, Shin and Smith (M Hashem Pesaran, Shin, \& Smith, 1996). The study justified the adoption of ARDL based on its advantages over the residual-based (Engle \& Granger, 1987) and other cointegration tests (Johansen, 1988, 1991; Johansen \& Juselius, 1990; Phillips \& Hansen, 1990). The ARDL test can be applied irrespective of the different order of integration, whether the variables are integrated at level or first difference or mix order of integration (Bahmani-Oskooee \& $\mathrm{Ng}$, 2002; Mohammad Hashem Pesaran \& Pesaran, 1997). Another advantage of ARDL model is that it takes a sufficient number of lags to reduce the strength of the serial correlation of residuals (Laurenceson \& Chai, 2003).

The key assumptions of ARDL bound test states that all variables under examination should be integrated at level, first difference or mixed order (M Hashem Pesaran, Shin, \& Smith, 2001). Pesaran et al. (2001) reported two sets of critical value; one states that all variables are integrated at level $(\mathrm{I}(0))$ and the second states that all the variables are integrated at first difference $(I(1))$. Hence, the study proposed to consider Augmented Dickey-Fuller (ADF) and Phillips-Perron (PP) unit root tests to ensure that none of the variables is integrated at the second order. The justification of the unit root test is to avoid violation of the assumption. ADF and PP unit root tests are commonly used in the stationary test (Abd Karim \& Gee, 2008).

The ARDL model considered in the present study can be written as:

$$
R R_{t}=\alpha 0+\alpha_{1} G D P_{t}+\alpha_{2} C P I_{t}+\alpha_{3} R E E R_{t}+\alpha_{4} S H P I_{t}+\alpha_{5} U E R_{t}+\alpha_{6} L T I R_{t}
$$$$
+\alpha_{7} S T I R_{t}+\varepsilon_{t}
$$

where $R R$ represent rental rate as the dependent variable. The macroeconomic determinants used as the independent variables in the equation are $G D P=$ real Gross Domestic Products, $C P I=$ consumer price index, REER = real effective exchange rate, $S H P I$ $=$ share price index, $U E R=$ unemployment rate, $L T I R=$ long-term interest rate and $S T I R=$ short-term interest rate. All the variables are converted to the natural logarithms. In the equation (equation 3.1), $\alpha 0$ is the constant and $\alpha_{1} \ldots \alpha_{n}$ represent the coefficient of specific macroeconomic variables. The term $\varepsilon$ is referred to as the error term. The error term is defined as the residual error of the regressions and $t=1 \ldots \mathrm{n} ; T$ refers to the time series period. The variables $\alpha_{6}$ and $\alpha_{7}$ are expected to be an insignificant relationship based on Islamic home finance in order to ensure that rental rate is free from the influence of interest rates for the objective to be achieved. Tables 3.1 shows the variables and their measurement as well as the sources of data used in the present study.

Table 3.1: Measurement of Variables

\begin{tabular}{|c|c|c|c|}
\hline Variables & Measurement & period & Sources \\
\hline Rental rate & Rental price & 1990Q1- & stats.oecd.org \\
& index & 2016Q4 & \\
\hline Interest rates & Short-term/ & $1990 \mathrm{Q} 1-$ & stats.oecd.org \\
& long-term & $2016 \mathrm{Q} 4$ & \\
\hline Income & real GDP & $1990 \mathrm{Q} 1-$ & imf.org \\
& & $2016 \mathrm{Q} 4$ & \\
\hline Inflation rate & Consumer price & $1990 \mathrm{Q} 1-$ & stats.oecd.org \\
& index & $2016 \mathrm{Q} 4$ & \\
\hline Exchange rate & Real effective & $1990 \mathrm{Q} 1-$ & imf.org \\
\hline
\end{tabular}

\begin{tabular}{|c|c|c|c|}
\hline & exchange rate & 2016Q4 & \\
\hline $\begin{array}{c}\text { Unemployment } \\
\text { rate }\end{array}$ & Harmonized & $1990 \mathrm{Q} 1-$ & data.oecd.org \\
& $\begin{array}{c}\text { unemployment } \\
\text { rate }\end{array}$ & $2016 \mathrm{Q} 4$ & \\
\hline Share price & Share price & $1990 \mathrm{Q} 1-$ & data.oecd.org \\
& index & $2016 \mathrm{Q} 4$ & \\
\hline
\end{tabular}

Source: IMF and OECD Data

The present study employed the ARDL bound test, proposed by Pesaran et al. (2001) to test the existence of long-run cointegration between the variables. The cointegration test is based on the null hypothesis which states no cointegration and the alternative hypothesis that states the existence of cointegration. The $F$-statistics is compared to Narayan (2004) two critical values (upper and lower values). If the result is above the upper critical value, the null hypothesis is rejected. This indicates the existence of cointegration. Whereas if the result is below the lower critical value, it indicates nonexistence of cointegration. However, if the result is between the two critical values, it indicates the inconclusive result. The further stage after establishing the existence of cointegration is long-run equilibrium and short-run dynamic. The last step of ARDL is to estimate the associated ARDL ECM. The lag error correction term $\left(e c t_{t-1}\right)$ measures the speed of the adjustment that stabilized disequilibrium of the model by converging to equilibrium. The significant negative relationship of the coefficient of error correction model confirms the existence of long-run relationship and adjustment of disequilibrium to ensure convergence of the dynamics to the long-run equilibrium in the model (Narayan, 2004). The high magnitude of the ECT indicates the high speed of adjustment. Therefore, the short run elasticity is estimated using ARDL error correction term (ECT). Therefore, a dynamic errorcorrection model (ECM) can be derived from the ARDL model equation 3.1 through a simple linear conversion (Banerjee, Dolado, Galbraith, \& Hendry, 1993). The error correction model representation of the ARDL models can be presented in the equation below:

$$
\begin{aligned}
\Delta R R_{t}= & \alpha_{0}+\sum_{j=1}^{k 1} \alpha_{1} \Delta R R_{t-j}+\sum_{j=0}^{k 2} \alpha_{2} \Delta G D P_{t-j}+\sum_{j=0}^{k 3} \alpha_{3} \Delta C P I_{t-j} \\
& +\sum_{j=0}^{k 4} \alpha_{4} \Delta R E E R_{t-j}+\sum_{j=0}^{k 5} \alpha_{5} \Delta \operatorname{SHPI}_{t-j}+\sum_{j=0}^{k 6} \alpha_{6} \Delta U E R_{t-j} \\
& +\sum_{j=0}^{k 7} \alpha_{7} \Delta \text { LTIR }_{t-j}+\sum_{j=0}^{k 8} \alpha_{8} \Delta S H T I R_{t-j}
\end{aligned}
$$

$+\beta_{1} R R_{t-1}+\beta_{2} G D P_{t-1}+\beta_{3} C P I_{t-1}+\beta_{4} R E E R_{t-1}+\beta_{5} S_{H P I} I_{t-1}+\beta_{5} U E R_{t-1}+$ $\beta_{6} L_{T I R}+\beta_{7-1} \operatorname{STIR}_{t-1}+\beta_{8} E C T_{t-1}+\varepsilon_{t}$

where the used variables are as defined in equations $3.1, k$ is the maximum number of lags in levels of the variables, $\Delta$ is the first difference operator, and $\alpha_{0}$ is constant, the parameters $\alpha_{s}$ correspond to the short run relations, whereas $\beta s$ correspond to the long run relations; ect is the error correction term, and $\varepsilon_{t}$ is the error terms. The summation signs in the equation 3.2 represent the error correction dynamics. Whereas the second part represents the long run aquarium (terms with $\beta_{\mathrm{s}}$ where $s$ represent $1,2, \ldots, 8$ ). $\beta_{8}$ indicates the speed of adjustment.

The last stage of ARDL model is the stability test proposed by Brown, Durbin and Evans (Brown, Durbin, \& Evans, 1975). The test consists of the cumulative sum of recursive residuals (CUSUM) and the cumulative sum of square recursive residuals (CUSUMSQ). The tests are presented in the form of graphs. The graph is examined with the two critical boundaries (upper and lower) of five percent significance level. If the graphs of CUSUM and CUSUMSQ fall inside the upper and lower boundaries, it indicates that the coefficients of the dependent variable in the ECT of the ARDL model are stable. Hence, the null hypothesis cannot be rejected. Conversely, the null hypothesis can be rejected if the 
graph is found to be across the boundary of critical value. The test examines the stability of short-term movement within the longterm parameter. The CUSUM test shows whether the coefficient of regressions are changing systematically and the CUSUMSQ shows whether the coefficient regressions are changing suddenly.

\section{Results and Findings}

\subsection{Unit Root Tests}

The analyst of the present study starts with the unit root test to ensure that none of the variables are integrated in the second order of integration. The regression of the model that consists of the second order integrated variables could produce a spurious result (Narayan, 2004; M Hashem Pesaran et al., 2001). Table 3.1 shows the result of the ADF unit roots and Table 3.2 shows the result of PP unit roots test. The result of ADF shows that CPI, LTIR, and STIR are integrated at level. While all the variables are integrated at first difference. The result of PP unit root test shows that CPI and LTIR variables are integrated at level and the all the variables are integrated at first difference. The results of the both ADF and PP show that none of the variables are integrated at second order. Hence, this justified the use of ARDL model.

Table 4.1: The Augmented Dickey-Fuller (ADF) Stationary Test Result

\begin{tabular}{|c|c|c|c|c|}
\hline Variables & \multicolumn{2}{|c|}{ level } & \multicolumn{2}{c|}{ First difference } \\
\hline & Constant & $\begin{array}{c}\text { Constant \& } \\
\text { Trend }\end{array}$ & Constant & $\begin{array}{c}\text { Constant } \& \\
\text { Trend }\end{array}$ \\
\hline CPI & $0.0326^{* *}$ & 0.9860 & $0.0000^{* * *}$ & $0.0000^{* * *}$ \\
\hline UER & $0.0527^{*}$ & 0.1558 & $0.0331^{* *}$ & 0.1253 \\
\hline LTIR & 0.7719 & $0.0235^{* *}$ & $0.0000^{* * *}$ & $0.0000^{* * *}$ \\
\hline REER & 0.3321 & 0.6905 & $0.0000^{* * *}$ & $0.0000^{* * *}$ \\
\hline GDP & 0.4903 & 0.9588 & $0.0006^{* * *}$ & $0.0000^{* * *}$ \\
\hline RPI & 0.8542 & 0.9142 & $0.0007^{* * *}$ & $0.0130^{* *}$ \\
\hline SHPI & 0.4526 & 0.4256 & $0.0000^{* * *}$ & $0.0000^{* * *}$ \\
\hline SITR & 0.5749 & $0.0000^{* * *}$ & $0.0000^{* * *}$ & $0.0000^{* * *}$ \\
\hline
\end{tabular}

Notes: Figures are the t-statistics for testing the null hypothesis that the series are non-stationary. * denote significance at $10 \%, * *$ denote significance at $5 \%$ and $* * *$ denote significance at $1 \%$.

Table 4.2: The Phillips-Perron (PP) Stationary Test Result

\begin{tabular}{|c|c|c|c|c|}
\hline Variables & \multicolumn{2}{|c|}{ level } & \multicolumn{2}{c|}{ First difference } \\
\hline & Constant & $\begin{array}{c}\text { Constant } \\
\& \text { Trend }\end{array}$ & Constant & $\begin{array}{c}\text { Constant \& } \\
\text { Trend }\end{array}$ \\
\hline CPI & $0.0326^{* *}$ & 0.9860 & $0.0000^{* * *}$ & $0.0000^{* * *}$ \\
\hline UER & $0.0527^{*}$ & 0.1558 & $0.0331^{* *}$ & 0.1253 \\
\hline LTIR & 0.7719 & $0.0235^{* *}$ & $0.0000^{* * *}$ & $0.0000^{* * *}$ \\
\hline REER & 0.3321 & 0.6905 & $0.0000^{* * *}$ & 0.6905 \\
\hline GDP & 0.4903 & 0.9588 & $0.0006^{* * *}$ & $0.0000^{* * *}$ \\
\hline RPI & 0.8542 & 0.9142 & $0.0007^{* * *}$ & $0.0130^{* *}$ \\
\hline SHPI & 0.4526 & 0.4256 & $0.0000^{* * *}$ & $0.0000^{* * *}$ \\
\hline SITR & 0.5749 & 0.4652 & $0.0000^{* * *}$ & $0.0000^{* * *}$ \\
\hline
\end{tabular}

Notes: Figures are the t-statistics for testing the null hypothesis that the series are non-stationary. $*$ denote significance at $10 \%, * *$ denote significance at $5 \%$ and $* * *$ denote significance at $1 \%$.

\subsection{Autoregressive Distributed Lags (ARDL)}

The ARDL is sensitive to the lag order (Bahmani-Oskooee \& Ng, 2002). Hence there is need to determine the lag order based on the lag selection information criteria. Akaike, Schwarz, and HannanQuinn are the three commonly used information criteria. The present study considers large observation number of 104. Akake Information Criteria (AIC) is more superior to Schwarz information criteria (SIC) in the large observation (Harvey \& Harvey, 1993). Therefore, the study considers four as the optimum number of lags as selected by the Akaike information criteria. According to (Liew, 2004), the lag with the smallest value is the appropriate lag for regression. Another justification for selecting lag four as the optimum is lag is that the lag agreed with both Akaike and Hannan-Quinn selection criteria, as indicates in Table 4.3.
Table 4.3: Lags Selection Criteria

\begin{tabular}{|c|c|c|c|}
\hline Lags & AIK & SIC & HQIC \\
\hline 1 & -9.384618 & -9.270650 & -9.270650 \\
\hline 2 & -9.385884 & -9.102799 & -9.271253 \\
\hline 3 & -9.812882 & $-9.450390^{*}$ & -9.666135 \\
\hline 4 & $-9.940307^{*}$ & -9.289014 & $-9.676717^{*}$ \\
\hline
\end{tabular}

Note: * indicates the lowest value

Therefore, considering four as the optimum lag, the ARDL come up with the selected model of lags $3,3,2,0,1,1,4$ and 3 for the RI, CPI, UER, LTIR, REER, GDP, SHPI and STIR respectively as presented in Table 4.4.

Table 4.4: Optimal ARDL Model Section

Selected Model: ARDL(3, 3, 2, 0, 1, 1, 4, 3)

\begin{tabular}{|l|l|l|l|l|}
\hline \multicolumn{5}{|l}{ Selected Model: ARDL $(3,3,2,0,1,1,4,3)$} \\
\hline Variables & Coefficient & Std. Error & t-Statistic & Prob. \\
\hline RI(-1) & 1.115231 & 0.087057 & 12.81028 & 0.0000 \\
\hline RI(-2) & 0.130062 & 0.125772 & 1.034110 & 0.3044 \\
\hline RI(-3) & -0.355903 & 0.077395 & -4.598509 & 0.0000 \\
\hline CPI & 0.045614 & 0.039867 & 1.144145 & 0.2562 \\
\hline CPI(-1) & -0.006248 & 0.053656 & -0.116448 & 0.9076 \\
\hline CPI(-2) & -0.013388 & 0.056397 & -0.237388 & 0.8130 \\
\hline CPI(-3) & 0.070576 & 0.041568 & 1.697853 & 0.0937 \\
\hline UER & -0.001846 & 0.006478 & -0.284996 & 0.7764 \\
\hline UER(-1) & 0.014323 & 0.009604 & 1.491303 & 0.1401 \\
\hline UER(-2) & -0.018440 & 0.006605 & -2.791993 & 0.0066 \\
\hline LTIR & 0.001476 & 0.001399 & 1.054728 & 0.2949 \\
\hline REER & -0.010570 & 0.008848 & -1.194645 & 0.2360 \\
\hline REER(-1) & 0.019107 & 0.009053 & 2.110631 & 0.0381 \\
\hline GDP & -0.020703 & 0.043553 & -0.475354 & 0.6359 \\
\hline GDP(-1) & 0.061040 & 0.040652 & 1.501511 & 0.1374 \\
\hline SHPI & -0.004674 & 0.003974 & -1.175986 & 0.2433 \\
\hline SHPI(-1) & 0.005665 & 0.005541 & 1.022444 & 0.3099 \\
\hline SHPI(-2) & -0.004186 & 0.005448 & -0.768333 & 0.4447 \\
\hline SHPI(-3) & 0.004779 & 0.005123 & 0.932907 & 0.3539 \\
\hline SHPI(-4) & -0.007709 & 0.003395 & -2.270934 & 0.0260 \\
\hline STIR & 0.000146 & 0.001169 & 0.125226 & 0.9007 \\
\hline STIR(-1) & 0.000666 & 0.001608 & 0.413904 & 0.6801 \\
\hline STIR(-2) & 0.000425 & 0.001584 & 0.268324 & 0.7892 \\
\hline STIR(-3) & -0.002116 & 0.001093 & -1.936624 & 0.0566 \\
\hline C & -0.119547 & 0.049446 & -2.417725 & 0.0180 \\
\hline F-stats & & \\
\hline
\end{tabular}

F-statistic value is 700399.04, and its probability is 0.000

\subsection{ARDL Bound Cointegration Test}

Having determined the optimum ARDL model the next stage is bound cointegration test. The ARDL bound test is considered to test the existence of cointegration among the independent variables and the dependent variable against the null hypothesis of none existence of cointegration. The study considers the United States quarterly data from 1990 to 2016 to test the influence of macroeconomic variables on the rental rate. The bound test result of $F$ statistics is 3.896870 as indicates in Table 4.5 below. The result indicates present of cointegration at five percent significance level. The finding provides support to the study of Salihu and Yusof (2017) which found cointegration relationship between house price and macroeconomic variables. The conclusion is based on Narayan (2004) table of critical value. The $F$-statistic below $I(0)$ indicates no cointegration, above $I(1)$ indicates present of cointegration and between $I(0)$ and $I(1)$ indicates the inconclusive result.

Table 4.5: ARDL Bound Test Results Rental Rate Model

\begin{tabular}{|c|c|c|c|c|c|}
\hline Variables & $\begin{array}{c}\mathrm{F} \\
\text { Statis- } \\
\text { tics }\end{array}$ & Cointegration & $\begin{array}{l}\mathrm{C} \\
\mathrm{V}\end{array}$ & $\begin{array}{l}\text { I( } \\
0)\end{array}$ & $\begin{array}{l}\text { I( } \\
1)\end{array}$ \\
\hline \multirow[t]{3}{*}{$\begin{array}{c}\text { FRR(CPI, } \\
\text { UER,LTIR,REER,GDP,SH } \\
\text { PI,STIR) } \\
\end{array}$} & $\begin{array}{c}3.8968 \\
70 * *\end{array}$ & $\begin{array}{l}\text { Present of } \\
\text { cointegration }\end{array}$ & $\begin{array}{l}1 \\
\%\end{array}$ & $\begin{array}{l}2 . \\
96\end{array}$ & $\begin{array}{l}4 . \\
26\end{array}$ \\
\hline & & & $\begin{array}{l}5 \\
\%\end{array}$ & $\begin{array}{l}2 . \\
32\end{array}$ & $\begin{array}{l}3 . \\
5\end{array}$ \\
\hline & & & $\begin{array}{l}10 \\
\%\end{array}$ & $\begin{array}{l}2 . \\
03\end{array}$ & $\begin{array}{l}3 . \\
13\end{array}$ \\
\hline
\end{tabular}

** represent five percent level of integration 


\subsection{Estimation of the Long-Run Relationships}

The study proceeds to the estimation of long-run parameters based on the result of the bound cointegration. The results of the long run relationship show that CPI and GDP have a significant positive relationship with the rental rate. However, the results indicate that SHPI and UER are negatively related to the rental rate. The positive coefficient of CPI and GDP means that one percent increase in CPI increases the rental rate by 0.872919 percent. Accordingly, one percent increase in GDP increases the rental rate by 0.364673 percent. The negative coefficient of SHPI and UER means that one percent decrease (increase) in SHPI increases (decreases) the rental rate by 0.055374 percent. Accordingly, one percent increase (decrease) in UER decreases (increases) the rental rate by 0.053911 .

The positive relationship between CPI and rental rate is consistent with the economic theory states that inflation positive affects the price of goods and services (Tze \& Yee, 2013). This includes rental rate as the price of services. The result is consistent with the study of Simon et al. (2015) which found a significant positive relationship between inflation rate and rental rate. The positive relationship between GDP and the rental price is consistent with the neoclassical consumption theory. Based on this theory, increase in the income level could motivate the rational consumer to maximize his or her utility to rent high luxury property. The result is consistent with the study of Yusof et al. (2011).

The negative relationship between SHPI and rental rate is based on the effect on two alternative investment sectors. Hence, investment of one sector negative affects the return of the other sector. The result is consistent with the theory that considered housing market and the stock market as an alternative to one another. Therefore, rental price as a return on property negative affect share price as a return on stocks (Bardhan, Datta, Edelstein, \& Kim, 2003; Égert \& Mihaljek, 2007). Similarly, the negative relationship between UER and the rental rate. The result is consistent with the study of Latif (2015). The result of long-run relationship indicates the insignificant influence of both long-term and shortterm interest rates on the rental rate as indicated in Table 4.6.

Table 4.6: Rental Rate Long-Run Elasticity

\begin{tabular}{|c|c|c|c|c|}
\hline \multicolumn{4}{|c|}{ Selected Model: ARDL $(3,3,2,0,1,1,4)$} & \\
\hline Variable & Coefficient & Std. Error & t-Statistic & Probability \\
\hline CPI & 0.872919 & 0.144335 & 6.047875 & $0.0000 * * *$ \\
\hline UER & -0.053911 & 0.023629 & -2.281594 & $0.0254 * *$ \\
\hline LTIR & 0.013342 & 0.012370 & 1.078566 & 0.2842 \\
\hline REER & 0.077181 & 0.054763 & 1.409367 & 0.1629 \\
\hline GDP & 0.364673 & 0.127273 & 2.865281 & $0.0054 * *$ \\
\hline SHPI & -0.055374 & 0.022392 & -2.472985 & $0.0157 * *$ \\
\hline STIR & -0.007946 & 0.004339 & -1.831504 & $0.0710^{*}$ \\
\hline C & -1.080801 & 0.410750 & -2.631290 & $0.0103 * *$ \\
\hline
\end{tabular}

Note: $* * *, * *$ and $*$ represent $1 \%, 5 \%$ and $10 \%$ significance level respectively

\subsection{Estimation of the Short-Run Relationships}

The study pays more emphasis on the influence of long-term and short-term interest rates to determine whether the rental rate is free from the impact of interest rates in the United State Islamic home financing. Table 4.7 showed that the result of the short-run relationship indicates the insignificant influence of both long-term and short-term interest rates on the rental rate. Therefore, the result of the short-run robust the result of the long-run relationship.

Table 4.7: Rental Rate Short-Run Elasticity Selected Model: ARDL $(3,3,2,0,1,1,4,3)$

\begin{tabular}{|c|c|c|c|c|}
\hline \multicolumn{5}{|c|}{ Selected Model: ARDL( $3,3,2,0,1,1,4,3)$} \\
\hline Variable & Coefficient & Std. Error & t-Statistic & Probability \\
\hline $\mathrm{D}($ LRI(-1)) & 0.225841 & 0.083326 & 2.710327 & $0.0083^{* * * *}$ \\
\hline $\mathrm{D}(\mathrm{LRI}(-2))$ & 0.355903 & 0.077395 & 4.598509 & $0.0000^{* * *}$ \\
\hline $\mathrm{D}(\mathrm{LCPI})$ & 0.045614 & 0.039867 & 1.144145 & 0.2562 \\
\hline $\mathrm{D}($ LCPI(-1)) & 0.013388 & 0.056397 & 0.237388 & 0.8130 \\
\hline $\mathrm{D}($ LCPI(-2)) & -0.070576 & 0.041568 & -1.697853 & $0.0937^{*}$ \\
\hline
\end{tabular}

\begin{tabular}{|c|c|c|c|c|}
\hline $\mathrm{D}$ (LHUEPR) & -0.001846 & 0.006478 & -0.284996 & 0.7764 \\
\hline $\mathrm{D}($ LHUEPR(-1)) & 0.018440 & 0.006605 & 2.791993 & $0.0066^{* * *}$ \\
\hline $\mathrm{D}($ LLGTIR) & 0.001476 & 0.001399 & 1.054728 & 0.2949 \\
\hline $\mathrm{D}($ LREER) & -0.010570 & 0.008848 & -1.194645 & 0.2360 \\
\hline $\mathrm{D}($ LRGDP) & -0.020703 & 0.043553 & -0.475354 & 0.6359 \\
\hline $\mathrm{D}($ LSHPI) & -0.004674 & 0.003974 & -1.175986 & 0.2433 \\
\hline $\mathrm{D}($ LSHPI(-1)) & 0.004186 & 0.005448 & 0.768333 & 0.4447 \\
\hline $\mathrm{D}($ LSHPI(-2)) & -0.004779 & 0.005123 & -0.932907 & 0.3539 \\
\hline $\mathrm{D}($ LSHPI(-3)) & 0.007709 & 0.003395 & 2.270934 & $0.0260^{* *}$ \\
\hline $\mathrm{D}($ LSHTIR) & 0.000146 & 0.001169 & 0.125226 & 0.9007 \\
\hline $\mathrm{D}($ LSHTIR(-1) $)$ & -0.000425 & 0.001584 & -0.268324 & 0.7892 \\
\hline $\mathrm{D}($ LSHTIR(-2)) & 0.002116 & 0.001093 & 1.936624 & $0.0566^{*}$ \\
\hline CointEq(-1) & -0.110610 & 0.024411 & -4.531207 & $0.0000^{* * *}$ \\
\hline
\end{tabular}

Note: $* * *, * * \& *$ represent $1 \%, 5 \%$ and $10 \%$ significance level respectively

\subsection{Stability Test}

The plotted CUSUM and CSUMSQ of the model of the study stay within the upper and lower critical bound at five percent significance level. This confirmed the stability of the model as depicted in Figure 4.1 and Figure 4.2. Therefore, both the stability tests of CUSUM and CUSUMSQ discovered the goodness of fit of the ARDL model used in the study.

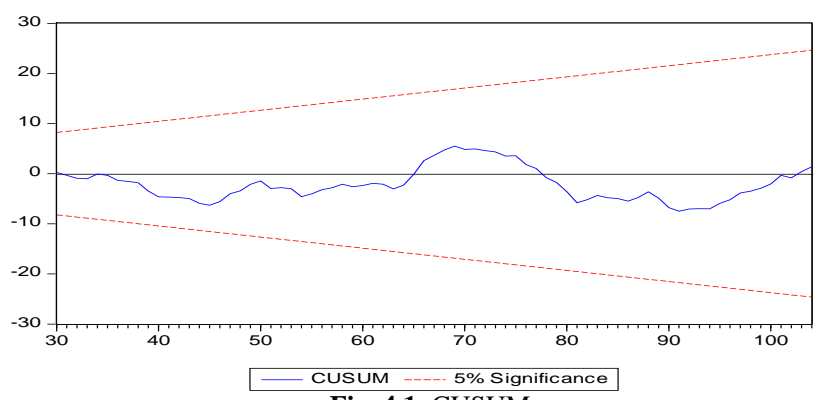

Fig. 4.1: CUSUM

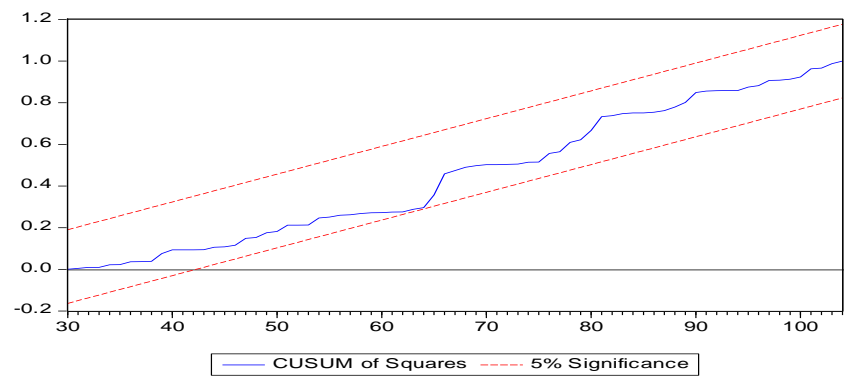

Fig. 4.1: CUSUMSQ

\subsection{Diagnostic Checks}

Apart from the above stability tests, the study considers Diagnostic checks to test normality, serial correlation and heteroskedasticity. The normality test on error terms confirmed that the model is normally distributed. The result of normality test indicates that the results failed to reject the null hypothesis which states that error term is normally distributed. Secondly, the serial correlation for the Lagrange Multiplier result points that the residual is not serially correlated. The result failed to reject the null hypothesis for the model that states the error terms are serially correlated. The nonexistence of serial correlation indicates good specification of the model. The third diagnostic test of heteroskedasticity test of errors failed to reject the null hypothesis which states that the residuals have constant variance (that is the existence of homoskedasticity). The result confirms the presence of homoskedasticity which is an indication of the absence of heteroskedasticity. Hence, this indicates the model is free from the problem of underestimating the variables and standard error. Therefore, as illustrated in Table 48, the ARDL error correction term confirms that the model is normally distributed, serially un- 
correlated, and the existence of homoskedasticity. Hence, this creates room for BLUE estimates.

Table 4.8: Rental Rate Model Diagnostic Tests

\begin{tabular}{|c|c|c|c|}
\hline Tests & Normality & Serial Correlation & Heteroskedasticity \\
\hline F-Statistics & 0.750352 & 1.724078 & 1.008817 \\
\hline Probability & 0.687168 & 0.1542 & 0.4667 \\
\hline
\end{tabular}

None of the tests is significant.

\section{Conclusion}

In the effort to determine whether the rental rate as a dependent variable is free from the impact of interest rates, the study examines the influence of macroeconomic variables on the rental rate in the United States Islamic home financing. The macroeconomic variables as the independent variables include UER, LTIR, REER, GDP, SHPI, and STIR. The study employed ARDL using the United States data of the variables from the first quarter of 1990 to the fourth quarter of 2016. The results of the long run equilibrium and short-run dynamic show that rental rate is free from the influence of both LTIR and STIR. In the context of the present study, rental rate is proposed as an alternative to the interest rate in Islamic home financing. Rental rate reflects on the real property estate returns that are considered as the real economic activities. The practical implication of the findings, however, if the interest rate is considered as a benchmark in Islamic home financing, the interest rate will continue to determine the rental rate.

The results of the findings further indicate that GDP, UER, CPI and SHPI influence the rental rate. In spite of that the main objective of the study is achieved, the study has some limitations. The paper recommends the future study to focus on the impact of attributes such as physical structure and location of the property. These features of the property play a significant role in determining the rental price of the property.

\section{References}

[1] Abd Karim, M. Z., \& Gee, C. S. (2008). Stock market integration between Malaysia and its major trading partners (1994-2002).

[2] Alharbi, A. (2015). Development of the Islamic Banking System. Journal of Islamic Banking and Finance, 3(1), 12-25.

[3] Bahmani-Oskooee, M., \& Ng, R. C. W. (2002). Long-run demand for money in Hong Kong: an application of the ARDL model. International Journal of Business and Economics, 1(2), 147.

[4] Banerjee, A., Dolado, J. J., Galbraith, J. W., \& Hendry, D. (1993) Co-integration, error correction, and the econometric analysis of non-stationary data. OUP Catalogue.

[5] Bardhan, A. D., Datta, R., Edelstein, R. H., \& Kim, L. S. (2003). A tale of two sectors: Upward mobility and the private housing market in Singapore. Journal of Housing Economics, 12(2), 83-105.

[6] Brown, R. L., Durbin, J., \& Evans, J. M. (1975). Techniques for testing the constancy of regression relationships over time. Journal of the Royal Statistical Society. Series B (Methodological), 149-192.

[7] Égert, B., \& Mihaljek, D. (2007). Determinants of house prices in central and eastern Europe. Comparative economic studies, 49(3), 367-388.

[8] Engle, R. F., \& Granger, C. W. (1987). Co-integration and error correction: representation, estimation, and testing. Econometrica: journal of the Econometric Society, 251-276.

[9] Fauziah, Taib, M., Ramayah, T., \& Abdul Razak, D. (2008). Factors influencing intention to use diminishing partnership home financing. International Journal of Islamic and Middle Eastern Finance and Management, 1(3), 235-248

[10] Harvey, A. C., \& Harvey, A. C. (1993). Time series models (Vol. 2): Harvester Wheatsheaf New York.

[11] Johansen, S. (1988). Statistical analysis of cointegration vectors Journal of economic dynamics and control, 12(2-3), 231-254.

[12] Johansen, S. (1991). Estimation and hypothesis testing of cointegration vectors in Gaussian vector autoregressive models. Econometrica: journal of the Econometric Society, 1551-1580.

[13] Johansen, S., \& Juselius, K. (1990). Maximum likelihood estimation and inference on cointegration-with applications to the demand for money. Oxford Bulletin of Economics and statistics, $52(2), 169-210$

[14] Latif, E. (2015). Immigration and housing rents in canada: A panel data analysis. Economic Issues, 20(1), 91-108.

[15] Laurenceson, J., \& Chai, J. C. (2003). Financial reform and economic development in China: Edward Elgar Publishing.

[16] Liew, V. K.-S. (2004). Which lag length selection criteria should we employ?

[17] Marco, L. (2008). Determinants of New York City residential rental prices. Michigan journal of business, 1(2), 61-83.

[18] Meera, A., \& Abdul Razak, D. (2005). Islamic home financing through Musharakah Mutanaqisah and Al-Bay'Bithaman Aji contracts: A comparative analysis. Review of Islamic Economics, 9(2), 5-30.

[19] Meera, A., \& Abdul Razak, D. (2009). Home financing through the musharakah mutanaqisah contracts: some practical issues. Journal of Islamic Economics, 22(1), 3-27.

[20] Muhamad, S. F., \& Rahman, A. H. A. (2013). An evaluation on Musharakah Mutanaqisah based house financing by Islamic banks in Malaysia.

[21] Narayan, P. (2004). Reformulating critical values for the bounds Fstatistics approach to cointegration: an application to the tourism demand model for Fiji (Vol. 2): Monash University Australia.

[22] Osmani, N. M., \& Abdullah, M. F. (2010). Musharakah mutanaqisah home financing: A review of literatures and practices of Islamic banks in Malaysia. International Review of Business Research Papers, 6(2), 272-282.

[23] Pesaran, M. H., \& Pesaran, B. (1997). Working with Microfit 4.0. interactive econometric analysis;[Windows version]: Oxford University Press.

[24] Pesaran, M. H., Shin, Y., \& Smith, R. J. (1996). Testing for the'Existence of a Long-run Relationship': Faculty of Economics, University of Cambridge.

[25] Pesaran, M. H., Shin, Y., \& Smith, R. J. (2001). Bounds testing approaches to the analysis of level relationships. Journal of applied econometrics, 16(3), 289-326.

[26] Phillips, P. C., \& Hansen, B. E. (1990). Statistical inference in instrumental variables regression with I (1) processes. The Review of Economic Studies, 57(1), 99-125.

[27] Rama, A. (2010). Islamic benchmarking: An alternative to interest rate; Evidence from home financing in Malaysia. Paper presented at the Proceeding of the Conference on 4th Global Economic Direction, Kuwait University.

[28] Ranzini, S. L. (2007). Islamic finance (finally) taking roots in North America. Islamic Finance News, 4(13), 1-10.

[29] Salihu, J. A., \& Yusof, R. M. (2017). Macroeconomic determinants of housing prices: Empirical investigation of the South Africa housing market. Actual Problems of Economics, 8(194), 16-24.

[30] Simon, Z. Z., Achsani, N. A., Manurung, A. H., \& Sembel, R. (2015). The Determinants of Rental Rates and Selling Prices of Office Spaces in Jakarta: A Macroeconometric Model Using VECM Approach. International Journal of Economics and Finance 7(3), 165.

[31] Smolo, E., \& Kabir Hassan, M. (2011). The potentials of mushārakah mutanāqisah for Islamic housing finance. International Journal of Islamic and Middle Eastern Finance and Management 4(3), 237-258.

[32] Tze, S., \& Yee, S. (2013). Macroeconomic determinants of Malaysia housing market. Human and Social Science Research, 1(2), 119-127.

[33] Yusof, R. M., Kassim, S. H., Majid, M., \& Hamid, Z. (2011). Determining the viability of rental price to benchmark Islamic home financing products: evidence from Malaysia. Benchmarking: An International Journal, 18(1), 69-85. 